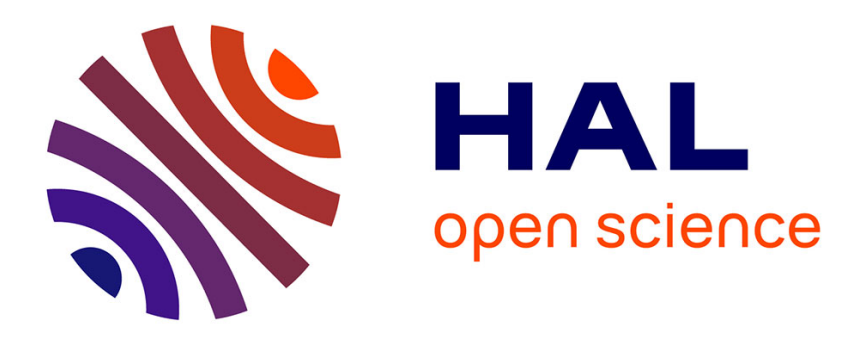

\title{
Adsorption of the first layer of argon on graphite Florence Millot
}

\section{To cite this version:}

Florence Millot. Adsorption of the first layer of argon on graphite. Journal de Physique Lettres, 1979, 40 (1), pp.9-10. 10.1051/jphyslet:019790040010900 . jpa-00231557

\section{HAL Id: jpa-00231557 https://hal.science/jpa-00231557}

Submitted on 1 Jan 1979

HAL is a multi-disciplinary open access archive for the deposit and dissemination of scientific research documents, whether they are published or not. The documents may come from teaching and research institutions in France or abroad, or from public or private research centers.
L'archive ouverte pluridisciplinaire HAL, est destinée au dépôt et à la diffusion de documents scientifiques de niveau recherche, publiés ou non, émanant des établissements d'enseignement et de recherche français ou étrangers, des laboratoires publics ou privés. 


\title{
Adsorption of the first layer of argon on graphite (*)
}

\author{
F. Millot \\ Laboratoire des Composés non Stœchiométriques, \\ Université de Paris-Sud, Centre d'Orsay, Bât. 415, 91405 Orsay, France \\ (Reçu le 10 août 1978, révisé le 7 novembre 1978, accepté le 13 novembre 1978)
}

Résumé. - Nous avons déterminé des isothermes d'adsorption d'argon sur le graphite entre 55 et $62 \mathrm{~K}$. Nous proposons une interprétation de nos résultats.

Abstract. - I have determined a set of adsorption isotherms for argon on graphite from 55 to $62 \mathrm{~K}$. An interpretation of the results is proposed.

Argon on graphite isotherms have been determined by volumetry with a modified MacLeod gauge previously described by Larher [1]. The cooling bath is solid nitrogen obtained by pumping. The adsorption cell, enclosed in an aluminium block, is regulated to within $0.01 \mathrm{~K}$. Using a nitrogen vapour pressure bulb and an oil manometer the temperature is known with a precision of $0.01 \mathrm{~K}$. Pressures are corrected for thermal transpiration [2] and mercury drag effect [3]. The graphite sample is an uncompressed grafoil from Union Carbide which was previously heated in vacuum at $400^{\circ} \mathrm{C}$. Its specific surface area is accurately determined from a nitrogen isotherm at $62 \mathrm{~K}$ (see

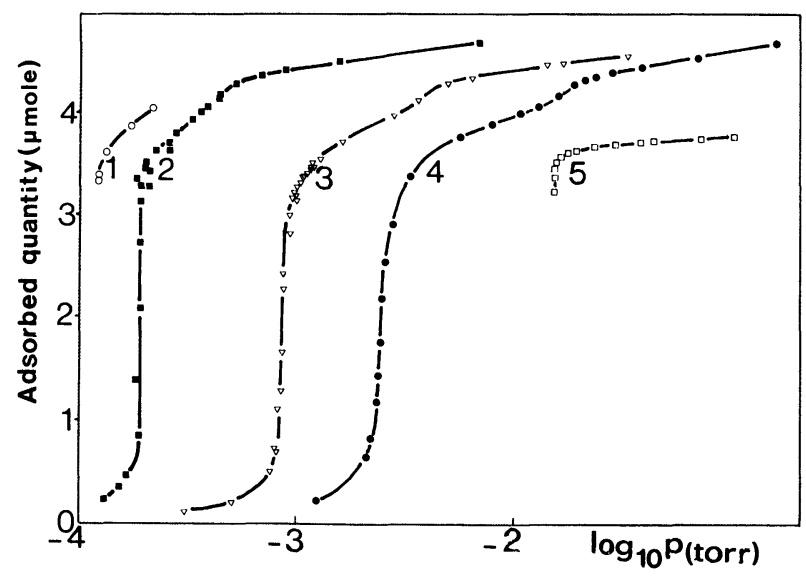

Fig. 1. - Adsorption isotherms for argon : 1) $54.61 \mathrm{~K}$;2) $55.75 \mathrm{~K}$; 3) $59.53 \mathrm{~K}$; 4) $62.41 \mathrm{~K}$, nitrogen ; 5) $62.11 \mathrm{~K}$ (uncorrected pressures).

${ }^{*}$ ) This paper has been presented at the LT 15 Conference as a post-deadline paper.
Fig. 1) as $26.5 \mathrm{~m}^{2} / \mathrm{g}$ (the end of the rise of isotherm 5 corresponds to the density of a registered $\sqrt{3} \times \sqrt{3}$ solid $[4,5])$. From the isotherms of figure 1 the critical temperature of the gas-dense phase transition was found to be $T_{\mathrm{c}}=58 \pm 1 \mathrm{~K}$. An accompanying isostere was made at $1.6 \mu$ mole (see Fig. 2). This data follows the linear fit

$$
\log _{10} p_{\text {(torr) }}=-\frac{607.5}{T}+7.14
$$

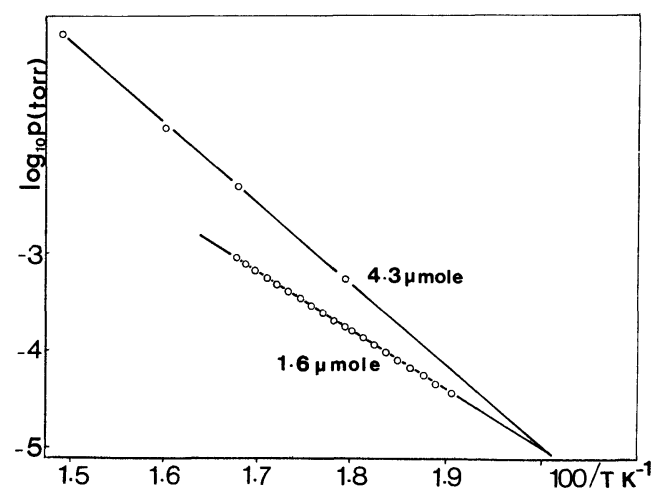

Fig. 2. - Isosteres at $1.6 \mu$ mole and $4.3 \mu$ mole. The highest pressure point is from Larher's work [4].

with standard deviations

$(607.5)=2.4$ and $(7.14)=0.04$

The relations between the vapour pressure of the transition $p^{(1)}$ and that of solid argon $p^{(\infty)}$ at the same temperature are [6] : 
$\log \frac{p^{(\infty)}}{p^{(1)}}=\frac{u^{(\infty)}-u^{(1)}}{R T}+\frac{s^{(1)}-s^{(\infty)}}{R}$

and

$\mathrm{d} \log \frac{p^{(\infty)}}{p^{(1)}} / \mathrm{d} \frac{1}{T}=\frac{u^{(\infty)}-u^{(1)}}{R}$.

From these relations the internal energy and entropy were deduced to be :

$u^{(\infty)}-u^{(1)}=3565 \pm 46 \mathrm{~J} \cdot \mathrm{mol}^{-1}$,

$s^{(1)}-s^{(\infty)}=11.7 \pm 0.8 \mathrm{~J} \cdot \mathrm{mol}^{-1} \cdot \mathrm{K}^{-1}$

respectively.

The nature of the dense phase formed during this first-order transition can be inferred in two ways. First, the end of the vertical rise of the $55.75 \mathrm{~K}$ isotherm corresponds to the density of the registered solid nitrogen when compared with the nitrogen isotherm of figure 1. Second, the entropy $s^{(1)}-s^{(\infty)}$ of the transition is compared in table $I$ and figure 3 to that of numerous registered phases of simple gases on lamellar halides. It has been shown [7] that the entropy of these transitions is sensitive to the dimensional incompatibility between the adsorbate and the adsorbent. In the particular case of a registered phase the dimensional incompatibility is the dilatation of the film from its natural 3D spacing. My result fits well with the curve of figure 3 for a solid argon layer dilated by $12 \%$ which corresponds to a $\sqrt{3} \times \sqrt{3} R 30^{\circ}$ registered phase. It is also shown that the entropy of the known $\sqrt{3} \times \sqrt{3} R 30^{\circ}$ phase of krypton on graphite [8] is consistent with this curve and that the data of Thomy and Duval [9] for xenon on graphite can be interpreted as a $2 \times 2$ registered phase instead of the liquid suggested by these authors. Diffraction techniques $[10,11]$ do not show any well ordered and registered solid argon monolayer. At least, neutrons [11] show at $55 \mathrm{~K}$ and a density of $0.062 \AA^{-2}$ an argonargon spacing close to the registered spacing. A compression of the solid out of registry is seen on the $55.75 \mathrm{~K}$ isotherm above $3.45 \mu$ mole. A new break occurs at $4.3 \mu$ mole. At this point the density of the film corresponds to a triangular lattice with argon atoms $3.8 \AA$ apart. This regime appears to be very
Table I. - Entropies and incompatibilities $i$ of registered phases of rare gases on graphite $\left(i=\frac{a-d}{d}, a\right.$ stands for the distance between two adsorption sites and $d$ for the natural 3D spacing of the adsorbate).

$\begin{array}{lccr}\begin{array}{l}\text { Adsorption } \\ \text { on graphite }\end{array} & \begin{array}{c}s^{(1)}-s^{(x)} \\ \mathrm{Jol}\end{array} \mathrm{mol}^{-1} \cdot \mathrm{K}^{-1} & \begin{array}{c}\text { Hypothetic } \\ \text { phase }\end{array} & i \% \\ \text { argon } & - & - & - \\ & 11.7 & \sqrt{3} \sqrt{3} R 30 & 12.0 \\ \text { krypton } & 1.1 & \sqrt{3} \sqrt{3} R 30 & 4.6 \\ \text { xenon } & 9.2 & 2 \times 2 & 11.7\end{array}$

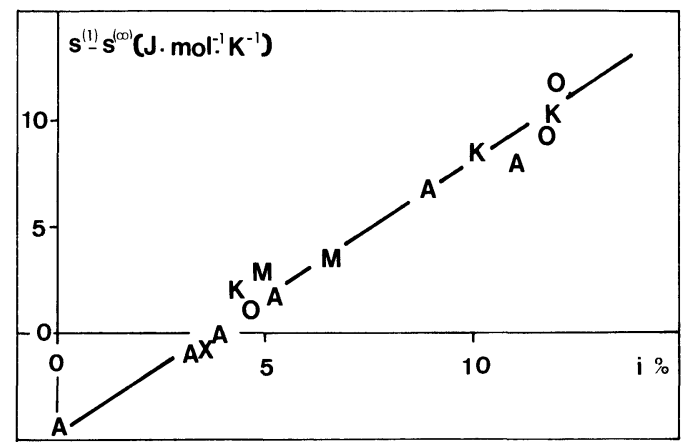

Fig. 3. - Entropy $v s$. incompatibility for argon (A), krypton (K), xenon $(\mathrm{X})$, methane $(\mathrm{M})$ on lamellar halides and rare gases on graphite (O).

different on the $59.53 \mathrm{~K}$ and $62.41 \mathrm{~K}$ isotherms. An ill-defined fluid-solid transition, already observed at higher temperatures by Grillet et al. [12] and Larher [13], takes place followed by a compression up to $4.3 \mu$ mole. The vapour pressure of the break points at $4.3 \mu$ mole is plotted on figure 2 . They lie on a straight line which crosses the gas to registered phase isostere at about $50 \mathrm{~K}$. This suggests the existence of a triple point and below $50 \mathrm{~K}$ a further gas to unregistered solid phase transition (Shaw and Fain [14] have shown that argon condenses at $51 \pm 1 \mathrm{~K}$ to an out of registry solid).

I am grateful to FINEP, CNPq and CEPG for financial support and to Michael Bretz for interesting discussions.

\section{References}

[1] Larher, Y., J. Chim. Phys. (1960) 1107.

[2] Takaishi, T. and Sensui, Y., Trans. Faraday Soc. 59 (1963) 2503.

[3] Takaishi, T. and Sensui, Y., Vacuum 20 (1970) 495, 539.

[4] KJems, J. K., Passell, L., Taub, H., Phys. Rev. Lett. 32 (1974) 724.

[5] Rouquerol, J., Partyka, S., Rouquerol, F., C.R. Hebd. Séan. Acad. Sci. C 282 (1976) 1057.

[6] Larher, Y., J. Colloid Int. Sci. 37 (1971) 836.

[7] Larher, Y. and Millot, F., J. Physique Colloq. 38 (1977) C4-189.
[8] Larher, Y., J. Chem. Soc. Faraday Trans. 170 (1974) 320.

[9] Tномy, A. and Duval, X., J. Chim. Phys. 67 (1970) 1101.

[10] Shaw, C. G., Fain, S. C., Chinn, M. D., Phys. Rev. Lett. 41 (1978).

[11] Taub, H., Carneiro, K., KJems, J. K., Passell, L., McTague, J. P., Phys. Rev. B 16 (1977) 4551.

[12] Grillet, Y., Rouquerol, F., Rouquerol, J., J. Physique Colloq. 38 (1977) C4-57.

[13] Larher, Y., J. Chem. Phys. 68 (1978) 22.

[14] Shaw, C. G. and Fain, S. C., unpublished. 